
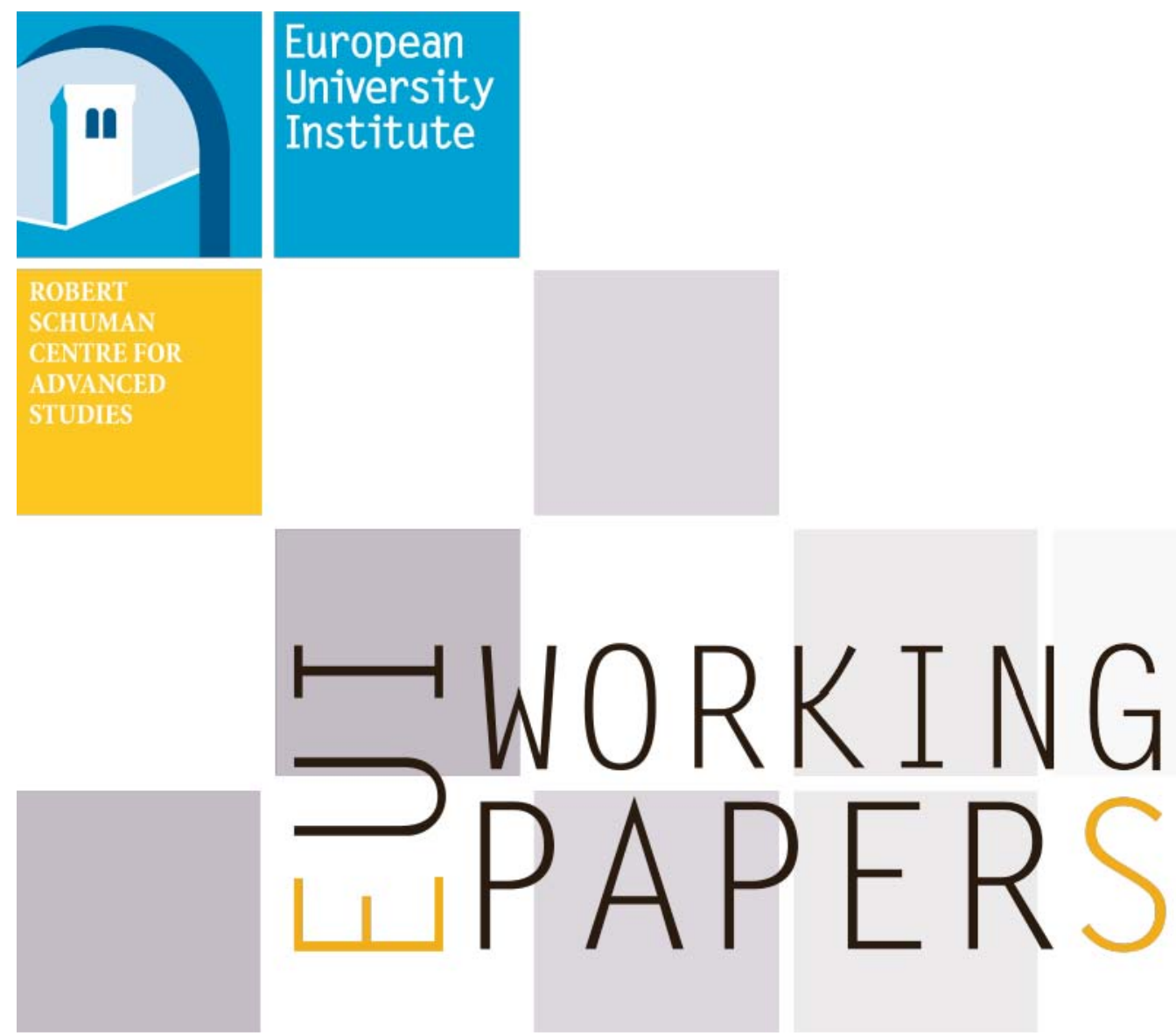

RSCAS 2018/30

Robert Schuman Centre for Advanced Studies Global Governance Programme-308

Labour market effects of currency appreciation: The case of Switzerland

Peter H. Egger, Johannes Schwarzer and Anirudh Shingal 

European University Institute

Robert Schuman Centre for Advanced Studies

Global Governance Programme

Labour market effects of currency appreciation:

The case of Switzerland

Peter H. Egger, Johannes Schwarzer and Anirudh Shingal

EUI Working Paper RSCAS 2018/30 
This text may be downloaded only for personal research purposes. Additional reproduction for other purposes, whether in hard copies or electronically, requires the consent of the author(s), editor(s). If cited or quoted, reference should be made to the full name of the author(s), editor(s), the title, the working paper, or other series, the year and the publisher.

ISSN 1028-3625

(C) Peter H. Egger, Johannes Schwarzer and Anirudh Shingal, 2018

Printed in Italy, June 2018

European University Institute

Badia Fiesolana

I - 50014 San Domenico di Fiesole (FI)

Italy

www.eui.eu/RSCAS/Publications/

www.eui.eu

cadmus.eui.eu 


\section{Robert Schuman Centre for Advanced Studies}

The Robert Schuman Centre for Advanced Studies, created in 1992 and currently directed by Professor Brigid Laffan, aims to develop inter-disciplinary and comparative research on the major issues facing the process of European integration, European societies and Europe's place in 21st century global politics.

The Centre is home to a large post-doctoral programme and hosts major research programmes, projects and data sets, in addition to a range of working groups and ad hoc initiatives. The research agenda is organised around a set of core themes and is continuously evolving, reflecting the changing agenda of European integration, the expanding membership of the European Union, developments in Europe's neighbourhood and the wider world.

For more information: http://eui.eu/rscas

\section{The Global Governance Programme at the EUI}

The Global Governance Programme is one of the flagship programmes of the Robert Schuman Centre. It is made of a community of outstanding professors and scholars, produce high quality research and engage with the world of practice through policy dialogue. Established and early career scholars research write on and discuss issues of global governance within and beyond academia, focusing on four broad and interdisciplinary areas: Global Economics, Europe in the World, Cultural Pluralism and Global Citizenship.

The Programme also aims to contribute to the fostering of present and future generations of policy and decision makers through its executive training programme: the Academy of Global Governance, where theory and 'real world' experience meet and where leading academics, top-level officials, heads of international organisations and senior executives discuss on topical issues relating to global governance.

For more information: http://globalgovernanceprogramme.eui.eu

The European University Institute and the Robert Schuman Centre are not responsible for the opinions expressed by the author(s). 



\title{
Labour market effects of currency appreciation: The case of Switzerland*
}

\author{
Peter Egger! Johannes Schwarzer ${ }^{\ddagger}$ and Anirudh Shingal ${ }^{\S}$
}

\author{
October 2017
}

\begin{abstract}
Recent work on labour market effects of globalization has generated both academic and populist interests. However, this work has focussed exclusively on the manufacturing sector. Moreover, general equilibrium effects of globalization have received little attention. This study contributes to filling both these gaps by examining the general equilibrium effects of external exposure on the labor market in Switzerland. We exploit exogenous exchange rate movements to identify trade-induced shocks across all sectors of the Swiss economy and transpose industry-level exposure to the municipal level, using detailed employment data on the entirety of Swiss firms. We find strong evidence for three channels of employment effects of currency appreciation - negative employment growth induced by increasing export uncompetitiveness and higher import competition, and positive employment growth induced by cheaper availability of foreign inputs. The combined average effect of the three channels on employment is found to be negative in our preferred results, with significant heterogeneity across municipalities.
\end{abstract}

JEL-Classification: F10, F14

Keywords: international trade, labour market, exchange rates, global value chains

*Funding from the Swiss State Secretariat for Economic Affairs (SECO) is gratefully acknowledged. $\dagger$ KOF, ETH Zürich. Email: egger@kof.ethz.ch

${ }^{\ddagger}$ Council on Economic Policies, Zurich. Email: js@cepweb.org

${ }^{\S}$ Corresponding author; European University Institute, Florence and World Trade Institute, University of Bern. Email: anirudh.shingal@eui.eu; anirudh.shingal@wti.org 



\section{Introduction}

The labor market effects of international trade in developed economies are the subject of intense public scrutiny and a major argument of anti-globalization movements. A series of recent studies (for instance see Autor et al. 2013, 2016) has established strong links between increased import competition notably from emerging markets and massive job dislocations and accelerated structural change in developed economies. However, insights into these links have been drawn almost exclusively on the basis of the manufacturing sector. Insufficient attention has been paid so far to labour market effects on the services sector in particular. Moreover, employment effects of globalization beyond increased import competition have received little attention in the empirical literature, though increased availability of trade in value added data has shed new light on global interconnectedness.

This study contributes to filling these gaps by examining the effects of external exposure on the labor market in Switzerland through the lens of an exporting channel and two distinct import channels. As a small open developed economy with relatively high integration in global value chains, Switzerland offers an ideal setting to examine labor market effects of external exposure. In order to do so, we exploit recent exogenous exchange rate movements to identify trade-induced shocks across all sectors of the Swiss economy and transpose industry-level exposure to the municipal level, using detailed employment data on the entirety of Swiss firms. This enables a more precise identification of the exchange rate shock as the extent of the shock varies across regions in Switzerland. In contrast, the shock at the aggregate level is collinear with other confounding influences. Moreover, we are also able to study the regional dimension of exchange rate changes in Switzerland as opposed to focussing on average effects for the whole country.

The Swiss Franc has appreciated considerably against major foreign currencies over the past decade, notably from 2008 onwards (see Figure 1). While the Swiss industrial structure plays an important role in the long term tendency of the Swiss Franc to appreciate, the recent appreciation has been the result of the Swiss Franc's "safe haven" status during the financial turmoil of the late 2000s (Baltensperger and Kugler, 2016). The continued appreciation of the $\mathrm{CHF}$ and the low inflation rates have raised fears about deflation tendencies and the loss of international competitiveness and resulting losses for Swiss exporters. In 2011, the Swiss National Bank (SNB) imposed a currency floor against the Euro, which was subsequently lifted in 2015. However, the strong and rapid appreciation of the Swiss Franc has been perceived as a challenge for large parts of the manufacturing sector, the tourism 
industry as well as retail trade and there has been widespread fear that a long-lasting strong Franc may even lead to an erosion of business locations in the country.

\section{$<$ Insert Figure 1 here $>$}

Our approach has two important advantages. First, we can track labour market outcomes of the CHF fluctuation across all economic sectors, without limiting our analysis to the manufacturing sector. Close to $74 \%$ of Swiss employment is currently in the services sector (not counting energy and construction) ${ }^{1}$. The services sector may be impacted indirectly through worker relocations and spillovers from the manufacturing and agricultural sectors as well as directly through exposure to international trade. Moreover, the services sector accounts for a large share of Swiss external trade: Swiss exports and imports of services amounted to CHF 105.45 billion and 85.04 billion respectively in 2014, as opposed to 208.36 billion and 178.61 billion in manufacturing the same year ${ }^{2}$. However, despite the importance of the services sector, previous studies on Switzerland and most studies on trade and employment more generally have been unable to account for effects beyond the manufacturing sector, which currently employs less than $17 \%$ of the Swiss workforce.

Second, our approach allows us to distinguish several channels through which exchange rates may impact the domestic economy. While existing studies generally emphasize import competition and/or export channels, we are able to distinguish a third channel that turns out to be crucial, but has hitherto been neglected in the empirical literature: the use of foreign intermediate inputs. While this third channel is more important for the Swiss manufacturing sector as a whole (see Table 2 for details), it is also significant for a few services: transport and storage, and renting of machinery and equipment, in particular. Data from the OECD-WTO TiVA database suggest that the foreign value added share of gross exports (used as a reliable measure of backward linkage in GVCs) in these sectors was 19.8\% and 18.4, respectively, in 2011 (the last year for which these data are available). Moreover, the Swiss manufacturing sector is also reliant on imported services inputs. Illustratively, data from the World Input Output Database (WIOD; Timmer et al. 2015) suggest that the Swiss computer, electronics and optics sector imported telecom services worth $\$ 135$ million from Germany in 2014 ; in the same year, Swiss pharma imported $\$ 1.47$ billion of health services from Germany.

\footnotetext{
${ }^{1}$ In the study, manufacturing comprises NOGA codes 15-37 and services comprises NOGA codes 50-52, $55,60-67,70-75,80,85,90-93$.

${ }^{2}$ https://www.eda.admin.ch/content/dam/dea/de/documents/faq/schweiz-eu-in-zahlen_de.pdf
} 
Our empirical strategy is informed by the theoretical predictions of Campa and Goldberg (2001). Conceptually, there are three ways in which the exchange rate may impact firms and hence workers. First, an appreciation makes domestic firms less competitive, which may translate into job losses within export-oriented firms. Appreciation makes domestic products more expensive relative to foreign products, leading to a decline in demand for domestic products and labour. On the import side, predictions depend on whether imported inputs are substitutes or complements to domestic labour. The former case occurs in import-competing sectors. In this case, an appreciation of the CHF makes imports of foreign goods cheaper, which ultimately results in the downsizing of these firms' workforces. In contrast, firms that rely heavily on foreign inputs may expand operations as their relative prices fall when the domestic currency appreciates, resulting in an increase in the demand for labour. For instance, the transport and storage sector relies on imported inputs such as transport equipment and fuel, whose prices dropped due to the appreciation of the Swiss Franc. Similarly, the appreciation makes it easier for Swiss renting companies to buy machinery and equipment in the EU and rent these to clients in Switzerland.

We find strong evidence for all three channels of employment effects of currency appreciation: negative employment growth induced by increasing export uncompetitiveness and higher import competition, and positive employment growth induced by cheaper availability of foreign inputs. The combined average effect of the three channels on employment growth is found to be negative in our preferred results, with significant heterogeneity across municipalities and for sub-samples that that consider industry concentration in terms of employment, dominant language spoken, high versus low shares of cross-border commuters, and rural versus urban regions. On average and ceteris paribus, a $1 \%$ appreciation of the export-, intermediate-input-, and import-weighted Swiss Franc is associated with a 0.12 percentage point decline in industry-weighted municpal employment growth. We also find our overall findings to be driven by the inclusion of the services sector in the analysis, which is consistent with the predominant role of the services sectors in both Swiss employment and trade.

The rest of the paper is structured as follows. Section 2 provides a brief review of the related literature. Section 3 describes the empirical methodology in detail, presenting the data sources, the construction of variables and the estimation strategy. Section 4 contains the main results of our analysis and Section 5 concludes. 


\section{Related literature}

Recent studies have investigated the effects of CHF fluctuations on Swiss economic performance along a number of dimensions. Using the KOF enterprise survey, Lassmann (2013) finds a negative impact of the CHF appreciation on firm profits. From an economic perspective, a temporary currency appreciation may even have permanent adverse impacts on exports. This "hysteresis effect"' has been studied by Fauceglia et al. (2015). At the same time, a high level of integration into global value chains (GVCs) could potentially mitigate these negative effects by simultaneously rendering foreign inputs cheaper. This "natural hedging"' has been confirmed in Fauceglia et al. (2014, 2015). Relative export resilience may also be explained by very low price elasticities of major Swiss exports such as pharmaceuticals and machinery, as suggested by Auer et al. (2011). However, Auer and Sauré (2012) caution that the failure to account for the simultaneous rebound of global demand and the strong Franc appreciation may lead to the wrong assumption that exchange rate fluctuations matter little for Swiss export performance.

To the best of our knowledge, the only study that explicitly looks at the link between Swiss Franc fluctuation and employment outcomes is Kaiser and Siegenthaler (2016). Using a panel of Swiss manufacturing firms based on the KOF innovation survey, the authors find that an appreciation increases high-skilled and reduces low-skilled employment in most firms, though the aggregate impact of the Swiss Franc appreciation seem to be muted in their findings.

In contrast to Kaiser and Siegenthaler (2016), we study the heterogenous effects of the Swiss CHF appreciation on employment across all sectors and regions, hitherto unexamined in this literature. This enables us to study the regional dimension of exchange rate changes in Switzerland as opposed to focussing on average effects for the whole country. To do so, we build on related studies by Campa and Goldberg (2001), Nucci and Pozzolo (2010), Autor et al. (2013), and Huang and Tang (2015). In particular, we decompose aggregate exchange rate fluctuation into an export-specific component, as well as two import-specific components that reflect both the degree of import competition and reliance on foreign inputs. 


\section{$3 \quad$ Empirical methodology}

\subsection{Data}

Our identification strategy requires detailed information about firms' exposure to exports, foreign sourcing and import competition. Unfortunately, no single Swiss data source provides sufficient information for our purposes. We hence need to make use of various data sources in order to construct accurate measures that reflect municipality level heterogeneity along those three lines. In this section, we discuss the various data sources and how we use them.

\subsubsection{Swiss employment according to the BZ and STATENT}

We are interested in the micro employment and industrial structure of the Swiss economy and hence our main datasets are the STATENT dataset and the Swiss business census (BZ), which is its predecessor. These datasets contain establishment-level data on the universe of Swiss firms and establishments, notably total employment, full-time equivalents (FTE), detailed location and industry classification of main economic activity (NOGA), as well as juridical form. The years of interest in the BZ dataset are 2001, 2005 and 2008, which is the last year before the strong and persistent CHF appreciation. We also make use of the STATENT dataset for the years 2011 and 2014 and maintain a three-year gap between time periods in our empirical analysis .

There are important methodological differences in the construction of the BZ and STATENT, which we need to account for. The main difference is that STATENT relies on administrative data, while BZ data comes from compulsory business censuses. The BZ has a somewhat higher threshold for registering employees and establishments (all employees that work at least 6 hours a week and all establishments in which at least 20 hours per weeks are being worked) than STATENT (all employees and establishments subject to social security contributions).

$<$ Insert Figure 2 here $>$

In Figure 2, we plot different statistics of the entire database if we restrict the sample to firms with fte $\geqslant 0.5$. The dotted line measured on the right vertical axis shows the evolution of Swiss FTEs over time. We observe a sharp increase in this evolution beginning 
in 2005 i.e. with the methodology of the old BZ dataset. There is a slight indication of a structural break when moving to the Statent methodology in 2011, as can be observed in the falling rate of increase of total FTEs post-2011. The structural break is more visible when looking at shares, as reflected on the left vertical axis. The dashed line tracks the evolution of the share of firms with $F T E \geqslant 0.5$ over the total number of firms registered in the respective datasets. This share drops significantly from over $95 \%$ in BZ to up to $85 \%$ in Statent, suggesting a higher sampling rate of micro-enterprises. However, in terms of FTE, the difference is rather marginal (the solid line), suggesting the presence of a large number of Swiss firms (15\% of the total) that generate less than $2 \%$ of total full time equivalent employment. Figure 2 hence suggests that we can effectively correct for the sampling bias by restricting the sample to those firms with at least 0.5 FTE, which is why we depart from standard practice of working without one-person companies i.e. FTE $\geqslant 1.0^{3}$.

When following municipalities over time, we face another challenge in that a large number of municipalities has undergone mutations over the period of observation. Most have been fusions, which we can track over time. BZ and STATENT each provide consistent identification codes for their respective datasets. However, in order to compare STATENT data with BZ data, we prefer to simply work with time-consistent municipalities across both datasets, yielding a total of 2284 municipalities that comprise more than $97 \%$ of Swiss employment. ${ }^{4}$

The economic sectors reported in these data follow the NOGA classification, which underwent a substantial change in nomenclature in 2008. The NOGA08 codes are reported for all firms, while the old NOGA02 cods are reported only until 2008. In our analysis, we work with industry data at the 2-digit ISIC Rev.3 classification. We therefore need to obtain time consistent NOGA codes that indicate the sector of economic activity. In order to do so, we first aggregate each firm's economic activity into the corresponding 2digit NOGA08 code. We then compute the corresponding NOGA02 code using correlation tables obtained from the Swiss Federal Statistic Office, taking due account of transition probabilities when codes do not map one-to-one into each other . ${ }^{5}$ NOGA02 is analogous

\footnotetext{
${ }^{3}$ This said, our overall findings are robust to restricting the sample to FTE $\geqslant 1.0$ instead of FTE $\geqslant 0.5$.

${ }^{4}$ This means that firms in close to 70 municipalities were not taken into account in the analysis as these municipalities underwent mutations over the period of analysis. However, since these mutations are likely uncorrelated with municipalities' international exposure, excluding them is unlikely to be a source of bias in the analysis. Note also that Glarus is not in the study's sample as they had a fusion of their municipalities to three municipalities.

${ }^{5}$ By considering sectors rather than firms we face the same problem as every other study associating the activity of firms with sectors and industries. In particular, bigger firms are active in more than one
} 
to ISIC Rev. 3 at the two digit level, which allows us to obtain exact correspondences between employment and industry output and trade data that we need for our analysis. It turns out that trade data are aggregated into 33 distinct industries (excluding households) in the OECD's input-output tables that we also need for our analysis (see Section 3.1.2). We therefore follow the same methodology to map NOGA02 codes into the 33 industries that are used in OECD's input-output tables. We provide the this industry mapping in columns (1) and (2) of Table 1.

\section{$<$ Insert Table 1 here $>$}

Table 1 also displays a number of key summary statistics. At the aggregate level, Swiss employment went up by $20.45 \%$ from 2001 to 2014. This aggregate growth, however, masks important structural changes at the industry level. In particular, the manufacturing sector (shaded) shed labor relative to other sectors, as well as in absolute terms (note that this study defines the manufacturing sector excluding the energy and construction sectors). While there were roughly 635,162 FTEs active in manufacturing in 2001, that number was reduced by 2,779 to 632,383 FTEs in 2014. While manufacturing share in total employment was almost $20 \%$ in 2001, that share was reduced to $16.5 \%$ in 2014 (the sums of columns 3 and 4 over the shaded area). In fact, the only manufacturing industries that experienced positive growth (column 4) over the sample period, while contributing substantially to overall employment growth (column 5) were "food products, beverages and tobacco", "chemicals and chemical products", as well as "computer, electronic and optical equipment". These industries are the usual suspects of the Swiss manufacturing scene and include local food giants, the pharmaceutical, as well as the emblematic Swiss watch industry.

In contrast to manufacturing, employment growth was driven almost entirely by the services sector over the sample period. Without counting "electricity, gas and water supply" and "construction", the services sector accounted for more than $95 \%$ of total employment growth in Switzerland. More than $33 \%$ of total employment growth originated in "R\&D and other business activities", of which most expansion originated in the business service sector (NOGA02 code 74 ). This sector alone expanded by $82 \%$ since 2001 , adding

sector but all of their employees are assigned to the sector of the main activity of the firm, no matter whether they work in that sector or not. Unfortunately, this problem cannot be circumvented due to data availability constraints in the context of this study and it is impossible to gauge whether and in which way it affects the results. 
216,646 new FTE jobs to the economy, which corresponds to almost $7 \%$ of total employment in 2001. The second largest contribution to total employment growth (25\%) was in the "health and social work" sector, which, however, grew less dynamically (56\%). Except for postal and telecommunication and hotels and restaurants, each services industry contributed positively to employment growth in Switzerland over time.

While structural transformation from manufacturing into services is a common phenomenon in developed economies, existing work that studies the relationship between trade and employment generally focuses solely on the manufacturing sector. Given the preceding discussion of employment trends in Switzerland, it should be clear that such studies portray only a partial picture of modern economic realities.

\subsubsection{Data on Swiss industry output, trade and bilateral exchange rates}

Both BZ and STATENT do not record any data on output or trade activity. We hence need to combine our employment dataset with external data on output and trade. The way this is usually done in the literature is through customs records, which generally maintain detailed records on products flowing into and out of a country. However, we cannot follow this approach for two main reasons.

First, customs record only data on trade in goods. However, trade in goods accounts for only part of international trade. As mentioned in the introduction, Swiss services trade amounts to roughly half of Swiss goods trade, according to Swiss balance of payments data. Simply excluding the services sector - which accounts for over $95 \%$ of employment gains in Switzerland - is likely to bias the empirical analysis.

Second, the product classification used to register goods does not have a direct correspondence with the classification of economic activity of the firm that participates in international trade. Using correspondence tables to map these products to the industry of origin, which are widely used in the trade literature and readily available from e.g. EUROSTAT, we can associate the entirety of Swiss traded products exclusively with the manufacturing sectors in which they originate. As such, we can use goods trade as a proxy for export exposure of manufacturing firms, as well as the degree of import competition. However in doing so, we would completely miss out on the channel of reliance on foreign inputs. Given that customs data is recorded in gross terms, as opposed to value added, this shortcoming substantially distorts any indicator that is measured in such a way. Moreover, the correspondence obtained through such tables is far from being exact. For example, when 
calculating the degree of export exposure as yearly total (manufacturing) industry exports as a share of industry gross output, obtained from Swiss Value Added Tax data, the shares range from 0 to over 1 in some cases, while, by definition, that number cannot be greater than 1.

In order to work with a unified framework, and given the above-mentioned shortcomings of the standard approach in the literature, we decided to make use of the OECD's InterCountry Input-Output (ICIO) database (OECD, 2015), which provides the basis for the joint WTO-OECD Trade in Value Added project. The ICIO database provide us with an excellent basis for our purposes. First, it comprises bilateral trade data for both goods and services, for years that mainly overlap with our Swiss employment data ${ }^{6}$. Second, the ICIO database differentiates 34 industrial activities ${ }^{7}$, which we can map one-to-one with Swiss employment data, given the consistent use of ISIC Rev.3 classifications (see Section 3.1.1). The sectors comprise all manufacturing and services industries and we are hence able to include the entirety of Swiss industries in the analysis. Third, unlike national input-output tables, including those available for Switzerland, ICIO provides for detailed inter-industry and final demand relationships across 61 economies, allowing us to construct very precise measures of industry-level exposure to changes in bilateral exchange rates, GDP and trade.

We thus obtain bilateral data on Swiss trade with 60 countries $^{8}$, as well as one "Rest of the World" aggregate economy. As the construction of our variables of interest (see Section 3.2) required detailed information on industry- and country-specific weights, we decided to drop the aggregate economy in our analysis, as it combines all remaining countries with various levels of exchange rates and GDP into one. It turned out that this aggregate economy accounted for less than $7 \%$ of Swiss trade flows over the period of observation.

\section{$<$ Insert Table 2 here $>$}

Table 2 summarizes key statistics of the ICIO trade data for Switzerland. The first column shows each industry's export intensity, defined as total exports over total output. We

\footnotetext{
${ }^{6}$ Note that ICIO data are not available for the year 2001. After verifying the consistency with Swiss Federal Customs trade data, we used 2000 ICIO data with 2001 BZ data.

${ }^{7}$ Note that the effective number of industries is 33 as we exclude the "Households" sector.

${ }^{8}$ These include Argentina, Australia, Austria, Belgium, Bulgaria, Brazil, Brunei Darussalam, Canada, Chile, China, Colombia, Costa Rica, Cyprus, Czech Republic, Germany, Denmark, Spain, Estonia, Finland, France, United Kingdom, Greece, Hong Kong, Croatia, Hungary, Indonesia, India, Ireland, Iceland, Israel, Italy, Japan, Cambodia, South Korea, Lithuania, Luxembourg, Latvia, Mexico, Malta, Malaysia, the Netherlands, Norway, New Zealand, the Philippines, Poland, Portugal, Romania, Russia, Saudi Arabia, Singapore, Slovak Republic, Slovenia, Sweden, Thailand, Tunisia, Turkey, Taiwan, United States, Vietnam and South Africa.
} 
observe the highest ratios in the manufacturing sector, where exports often consist of a majority of sales. The services sector is on average much less export oriented, but nevertheless displays substantial outward orientation in a few subsectors such as "Wholesale and retail trade and repairs", "Hotels and restaurants", "Transport and storage", as well as "Financial intermediation". The second column displays a measure of import competition, defined as Swiss final consumption expenditure abroad as a share of the respective industry's total output. Very high shares are obtained in sectors that Switzerland does not have important industrial capacities (anymore) in, such as "Coke, refined Petroleum products and nuclear fuel", "Textiles, leather and footwear", and "Motor Vehicles". The final column reports a measure of reliance on foreign inputs, defined as the expenditure on industry inputs purchased abroad over total industry output. On average, Swiss industries, especially in manufacturing, display a high level of reliance on foreign inputs, which may be due to its relatively small domestic market. Column 3 shows that all Swiss industries rely to varying degrees on foreign inputs, though the reliance of the services sector, with the exception of transport and storage and renting of machinery and equipment, is much lower than that of manufacturing.

Finally, we combined the information on trade partners from the ICIO database with data on bilateral exchange rates from UNCTADStat and on GDP from the World Bank's World Development Indicators (WDI). We completed missing information in the WDI on GDP for Taiwan from the Taiwanese National Statistics Office.

\subsection{Construction of industry-level variables}

\subsubsection{Industry-level exchange rate measures}

While we are interested in regional heterogeneities, we first proceed by constructing industrylevel measures. Given that different industries trade more or less intensively with different countries, we need an exchange rate measure that reflects this fact. Aggregate trade weighted exchange rate indices are not sufficient for our purpose, as they do not reflect the industry-specific exposure to foreign currencies. Building on Goldberg (2004), we construct an industry-level exchange rate index as follows:

$$
\Delta e_{i, t}^{x}=100 * \sum_{j} \frac{x_{i, j, t-1}}{x_{i, t-1}} \frac{e_{j, t}-e_{j, t-1}}{e_{j, t-1}}
$$


where $e_{j, t}$ is the bilateral nominal exchange rate between Switzerland and country $j, \Delta e_{i, t}^{x}$ is the change in the export-weighted exchange rate industry $i$ is facing at time $t$, taking into account its previous exposure to exchange rate fluctuations with country $j$. The weighting term $\left(\frac{x_{i, j, t-1}}{x_{i, t-1}}\right)$ reflects industry $i$ 's trade exposure to country $j$ in terms of its export propensity. We weigh by previous period trade shares so as to avoid any contemporaneous correlation as yearly trade flows may have adjusted for exchange rate fluctuations during the same year.

Imports of consumption goods and inputs do not necessarily follow the same pattern. Depending on the product in question, these are likely to being sourced from countries other than the export destination. The calculation of the imported input-weighted exchange rate change, $\Delta e_{i, t}^{m i}$, follows equation (1) but with imported inputs replacing exports in the weights. For the analogous calculation of the import-weighted exchange rate change, $\Delta e_{i, t}^{m c}$, we calculate weights on the basis of imports undertaken by Swiss final demand sectors such as households and government purchases, instead of Swiss industry imports.

$$
\begin{aligned}
\Delta e_{i, t}^{m i} & =100 * \sum_{j} \frac{m i_{i, j, t-1}}{m i_{i, t-1}} \frac{e_{j, t}-e_{j, t-1}}{e_{j, t-1}} \\
\Delta e_{i, t}^{m c} & =100 * \sum_{j} \frac{m c_{i, j, t-1}}{m c_{i, t-1}} \frac{e_{j, t}-e_{j, t-1}}{e_{j, t-1}}
\end{aligned}
$$

We plot the average exchange rate changes across all time periods obtained for each industry in Figure 3.

\section{$<$ Insert Figure 3 here $>$}

The dispersion of values within each industry is key to our identification strategy and we observe significant differences between the average exchange rate changes across industries that are specific to exporting $\left(d e_{x}\right)$, import competition $\left(d e_{m c}\right)$ and reliance on foreign inputs $\left(d e_{m i}\right)$. By definition these differences are the result of differing intensities of each industry's geographical sourcing or export destinations. The diamond-shaped dots appear to display the least variation across industries, which suggest relatively similar geographical sourcing of intermediate inputs across Swiss industries. Significant variation, however, can be observed for both export and import competition specific exchange rate appreciation measures, which suggests higher industry-specificity in trade partners for final products 
than for intermediate inputs. For instance, Figure 3 suggests that the average exchange rate appreciation was stronger in the chemicals and chemical products sector than in the hotels and restaurant sector. This means that the chemicals and chemical products sector was oriented more strongly in its exports to countries with whom the Swiss Franc appreciated more strongly relative to the hotels and restaurant sector. Overall, the observed variation in Figure 3 justifies the calculation of industry-specific exchange rates as aggregate exchange rate measures would not pick up these differences.

Interestingly, the Swiss manufacturing sector appears to have experienced a much larger export-specific exchange rate appreciation, while the services sector displays relatively higher import-specific appreciation measures. Table 3 reports these measures as aggregated at the broad sectoral level. We observe that the manufacturing sector experienced an average appreciation of $10.55 \%$ over the sample period, whereas this magnitude was only $8.81 \%$ for the services sector, suggesting less external competitiveness pressures for its exports. The roles are reversed, however, when looking at the values of the import-specific measures, notably the import-competition specific exchange rate appreciation.

\section{$<$ Insert Table 3 here $>$}

\subsubsection{Industry-level foreign demand}

The timing of the CHF appreciation coincides with the financial crisis that broke out in 2009. In order to disentangle the effects of the CHF appreciation from those of the global slowdown in demand, we constructed an industry specific, trade weighted measure of world demand, in addition to year fixed effects in all regression specifications (see Section 3.4 for details). The inclusion of such a control variable is warranted by the predominant role of countries' GDP in determining trade relations. Since we look at both imports and exports, this variable captures more than just foreign demand - the trade effects net of the exchange rate variation due to variation in foreign economic activity. We constructed a measure of industry-level foreign demand as follows:

$$
\Delta G D P_{i, t}^{*}=100 * \sum_{j} w_{i, j, t} \frac{G D P_{j, t}-G D P_{j, t-1}}{G D P_{j, t-1}}
$$

where $G D P_{j, t}$ is the Swiss trading partner's GDP and $G D P_{i, t}^{*}$ is the trade weighted foreign GDP industry $i$ is facing at time $t$ and 


$$
w_{i, j, t}=\frac{x_{i, j, t-1}+m i_{i, j, t-1}+m c_{i, j, t-1}}{x_{i, t-1}+m i_{i, t-1}+m c_{i, t-1}}
$$

\subsubsection{Industry-level exposure to exports and imports}

We now turn to calculating the degree of industries' export orientation $\left(x e_{i, t}\right)$, reliance on foreign inputs $\left(m e i_{i, t}\right)$ and import competition $\left(\operatorname{mec}_{i, t}\right)$, which we define as

$$
x e_{i, t}=100 * \sum_{j} \frac{x_{i, j, t-1}}{O u t_{i, t-1}}
$$

where $x_{i, j, t-1}$ denotes industry $i$ 's exports to country $j$ and $O u t_{i, t-1}$ denotes its total output;

$$
\operatorname{mec}_{i, t}=100 * \sum_{j} \frac{x_{i *, j, t-1}}{O u t_{i, t-1}}
$$

where $x_{i^{*}, j, t-1}$ denotes Swiss final consumption of foreign industry $i^{*}$ s exports, and

$$
m e i_{i, t}=100 * \sum_{i^{*}, j} \frac{x_{i^{*}, j, t-1}}{O u t_{i, t-1}}
$$

where we consider industry $i$ 's total imports of foreign intermediate inputs from across industries $i^{*}$.

Data on these variables is presented in Table 2 and discussed in the text in the description of the ICIO database for Switzerland in Section 3.1.2.

\subsection{Constructing local measures}

Having constructed the full set of industry-specific variables, we next move to estimating their local counterparts. The BZ and STATENT data offer detailed information on local industrial structures that we exploit to this end. Specifically, we scale national estimates at the industry level to the Swiss municipal level, the identifying assumption being that the typical firm in an industry in a municipality shares the same features as the national industry, proportionally to its size relative to the entire industry. The choice of the scaling parameter is hence consistent with the stylized fact that firms engaging in international trade are typically very large (Bernard et al. (2011)). The industry level exposure to 
foreign exchange rate fluctuations and trade is hence proportionally apportioned to local size, as in Autor et al. (2013). Specifically, we calculate a municipality-specific scaling variable that reflects both its industry composition, as well as its relative size:

$$
I_{c, t}=\frac{1}{n} \sum_{i} \frac{L_{c, i, t-1}}{L_{i, t-1}} I_{i, t}
$$

where indicator variable $I=\left\{\Delta e^{x}, \Delta e^{m i}, \Delta e^{m c}, \Delta G D P^{*}, x e\right.$, mec, mei $\}, L=$ employment, $n=$ total number of industries and the subscript $c$ denotes municipality.

Descriptive statistics for the set of constructed municipality-variables are reported in Table 4. Our original employment dataset had observations for 2001, 2005, 2008, 2011, and 2014. Our industry trade dataset has observations on years 2001, 2005, 2008 and 2011, which we have used to account for the calculation of beginning of period exposures. As we compute growth rates on the dependent variable, we are left with a four period panel, namely 2005, 2008, 2011 and 2014. The total number of observations (9136) thus comprises 4 years and 2284 municipalities that we track over time.

\section{$<$ Insert Table 4 here $>$}

Table 5 gives us a good example of what our indices capture and of the heterogeneity in the exposure measures across Swiss municipalities. Table 5 reports the top ten Swiss municipalities in terms of export exposure in 2014, as well as their ranks in earlier periods. While the biggest Swiss municipalities in terms of employment head this ranking, we also find a number of relatively small municipalities that display similarly high levels of export exposure. For example, Kreuzlingen, Mendrisio and Sevelen together account for less than $7 \%$ of total employment in Zurich alone. Nevertheless, they have similar levels of export exposure $\left(x e_{c, t}\right)$. Sevelen alone has less than 2000 FTEs, corresponding to a little more than half a percent of employment in Zurich. The similar level of export exposure comes from the fact that Sevelen provides a large share of total Swiss employment in one particular industry that makes a large part of its revenues abroad. The table hence illustrates well the fact that the constructed measures reflect municipality exposure along two lines: 1) the share of municipal industry employment in total industry employment, irrespective of the total size of the community, and 2) the trade intensities of the respective industries that a particular municipality houses. It is this regional heterogeneity in the exposure measures that we exploit in our estimation strategy.

\section{$<$ Insert Table 5 here $>$}




\subsection{Estimation}

Our empirical strategy is informed by the theoretical predictions of Campa and Goldberg (2001). Conceptually, there are three ways in which the exchange rate may impact firms and hence workers. First, an appreciation makes domestic firms less competitive, which may translate into job losses within export-oriented firms. Appreciation makes domestic products more expensive relative to foreign products, leading to a decline in demand for domestic products and labour. On the import side, predictions depend on whether imported inputs are substitutes or complements to domestic labour. The former case occurs in import-competing sectors. In this case, an appreciation of the CHF makes imports of foreign goods cheaper, which ultimately results in the downsizing of these firms' workforces. In contrast, firms that rely heavily on foreign inputs may expand operations as their relative prices fall when the domestic currency appreciates, resulting in an increase in the demand for labour.

Consistent with this conceptual framework, the baseline estimating equation is as follows:

$$
\begin{aligned}
& \Delta L_{c, t}=\beta_{0}+\left(\beta_{1 x}+\beta_{2 x} x e_{c, t}\right) \Delta e_{c, t}^{x}+\left(\beta_{1 m i}+\beta_{2 m i} m e i_{c, t}\right) \Delta e_{c, t}^{m i}+\left(\beta_{1 m c}+\beta_{2 m c} m e c_{c, t}\right) \Delta e_{c, t}^{m c}+ \\
& \beta_{1} \Delta G D P_{c, t}^{*}+\beta_{2} x e_{c, t}+\beta_{3} m e i_{c, t}+\beta_{4} m e c_{c, t}+\gamma_{c}+\gamma_{t}+\epsilon_{c, t}
\end{aligned}
$$

We experiment with two different measures of the dependent variable in distinct specifications: municipal employment growth, $\Delta L_{c, t}^{1}$ defined as $\left(100 * \frac{L_{c, t}-L_{c, t-1}}{L_{c, t-1}}\right)$ and industryweighted municipal employment growth, $\Delta L_{c, t}^{2}$ defined as $\left(100 * \frac{1}{n} \sum_{i} \frac{L_{i, c, t}-L_{i, c, t-1}}{L_{i, t-1}}\right)$, with the latter being the preferred measure (see Section 4.2 for details).

$x e_{c, t}, m e i_{c, t}$, and $m e c_{c, t}$ denote the degree of export orientation, reliance on foreign inputs and import competition respectively for each Swiss municipality. Similarly, $\Delta e_{c, t}^{x}, \Delta e_{c, t}^{m i}$ and $\Delta e_{c, t}^{m c}$ are municipality-specific trade weighted exchange rate changes that municipalities face depending on their industry composition. A trade weighted measure of foreign GDP change $\triangle G D P *_{c t}$ serves as a municipality-specific gravity measure to correct for the intensity of trade relations that arises from economic strength. Note that we work with nominal exchange rates as we include year fixed effects in the empirical analysis, which fully capture any change in the consumer price index. Hence, using nominal vs real exchange rates in the present analysis would be equivalent.

We also include municipality-level fixed effects $\gamma_{c}$, as well as time fixed effects $\gamma_{t}$ to con- 
trol for idiosyncratic shocks at each point in time that are assumed to equally affect all industries.

Theory predicts negative coefficients $\beta_{1 x}$ and $\beta_{2 x}$, as well as $\beta_{1 m c}$ and $\beta_{2 m c}$. $\beta_{1 x}$ captures the export-specific exchange rate effect, whereas $\beta_{2 x}$ captures its interaction with export exposure of the municipality, which we expect to magnify the effect observed in $\beta_{1 x}$. The same reasoning allows us to interpret the other coefficients, but we expect the coefficient on the second block to be positive, as a positive employment effect through the availability of cheaper inputs is expected to prevail in those municipalities relying heavily on foreign intermediate goods.

By postulating the above regression, we assume that exchange rate changes are exogenous to employment growth. This can be justified for a number of reasons. First, Figure 1 suggests that there was an abrupt appreciation of the Swiss Franc relative to the Euro and even more so the British Pound - that does not have a continuous mapping to changes in macroeconomic variables in Switzerland prior to the shock. Moreover, in the regression we control for municipality and year fixed effects, which capture the universe of differences in employment growth across municipalities in the average year as well as average timespecific employment growth rate and macroeconomic changes across all municipalities. The latter ensures that common municipality-specific factors across all years and common yearspecific, macroeconomic factors across all municipalities cannot generate an endogeneity bias through omitted variable bias in the respective dimensions. For instance, the year fixed effects capture any common trend in inflation, technological progress or structural change across all municipalities. Similarly, the municiplaity-fixed effects capture long term trends in employment growth, urbanization, etc. that are specific to municipalities in the considered time span.

The above regression, through the spacing of the data in time across three-year intervals, permits an analysis of short-to-medium term responses of employment growth to change in the appreciation or depreciation of the exchange rate. Since most of the variation in the data happened in 2007, after which we only have data for two other time spans, and data only come in three-year spells, we cannot contrast short- and long-run responses of employment growth to exchange rate fluctutaions in this study and have to focus on the medium-term.

Notice also that Figure 1 suggests that key movements of the Swiss Franc to other currencies in the period of consideration happened by way of appreciations only. Hence, the episode of interest does not support an analysis of the eventual asymmetry of appreciations 
vs depreciations of the Swiss Franc relative to the currencies of Switzerland's other major trading partners. Overall this means that we cannot speak to the question of whether appreciation-induced changes in employment could be reversed or not by equivalent depreciations in the aftermath. This relates to the aforementioned impossibility to analyze the longevity of the experienced effects given the data and the time span.

\section{Results}

Before turning to the estimation of equation (8), we plot municipal employment growth, $L_{c, t}^{1}$, in boxplots in Figure 5. The median Swiss municipality is seen to have experienced positive employment growth in all periods except for 2001-2005. This result is remarkable, given the global economic downturn, which seems not to have had an impact on municipal employment growth in Switzerland. This is corroborated by the value of the mean municipal employment growth over the sample period of $3.76 \%$ as reported in Table 4 .

\section{$<$ Insert Figure 4 here $>$}

\subsection{Municipal employment growth}

The results from estimating the baseline equation with $L_{c, t}^{1}$ as the dependent variable are reported in Table (6), columns (1) and (2). Column (1) includes only changes in exchange rate measures and foreign demand, whereas in column (2) we also include interactions with respective trade exposures as regressors. Going back to equation (8), $\beta_{1 x}$ captures the export-specific exchange rate effect, whereas $\beta_{2 x}$ captures its interaction with export exposure of the municipality $\left(x e_{c, t}\right)$, which we expect to magnify the effect observed in $\beta_{1 x}$. Thus, in the absence of the interaction term, $\beta_{1 x}$ alone captures the emplyoment effect of the export-weighted exchange rate; when the interaction term is included, the effect if captured by $\left(\beta_{1 x}+\beta_{2 x} x e_{c, t}\right)$. The same reasoning follows the interpretation of the

coefficients $\left(\beta_{1 m i}, \beta_{2 m i} m e i_{c, t}\right)$ with respect to the intermediate inputs channel and of the ceofficients $\left(\beta_{1 m c}, \beta_{2 m c} m e c_{c, t}\right)$ with respect to the import competition channel.

\section{$<$ Insert Table 6 here $>$}

In column (1), we observe a statistically significant negative coefficient on the importcompetition specific exchange rate, suggesting negative employment effects of the Swiss 
Franc appreciation through this channel, though the coefficient of the export-specific exchange rate is found to be statistically indifferent from zero. Everything else equal, an appreciation of the Swiss Franc fosters a substitution in consumption towards relatively cheaper foreign goods. However, we also estimate a very large and precisely estimated positive coefficient on the intermediate-inputs specific exchange rate, which is consistent with the "natural hedging" mechanism found in Fauceglia et al. (2014). Being a small open economy with a relatively limited domestic economy, Swiss firms are closely interwoven in global value chains and source important parts of their inputs from abroad. Everything else equal, the relative fall in prices of these foreign inputs gives them a competitive edge, which leads to positive employment growth. Moreover, when comparing the magnitudes of the estimated coefficients in column (1), we find a much larger positive effect on the intermediate-imports channel than the negative effect on the import competition channel. In column (2), we include the interaction terms that reflect the exposure of each municipality to the three channels of exchange rate change transmission. It turns out that only the coeffcients $\beta_{2 x}$ and $\beta_{2 m i}$ are statistically significant now; all other coefficientsincluding that of $\Delta G D P *_{c t}$, are statistically indifferent from zero ${ }^{9}$. Once again, we find a larger positive effect on the intermediate-imports channel than the negative effect on the export channel.

Note that the measure of the dependent variable employed in these regressions does not allow us to track where the growth of employment originates, or which industries have contributed to it. This is likely responsible for the imprecise estimation of the exchange rate effects via the three channels, reflected in the absence of statistical significance of the relevant coefficients in the results reported in columns (1) and (2), respectively. We therefore consider an alternative measure of the dependent variable below, which defines our preferred specification.

\subsection{Industry-weighted municipal employment growth}

One problem with total municipal employment growth as the dependent variable is that it does not provide an identification of the source of growth by industry. Illustratively, let's assume that municipality A's employment grows entirely through additional restaurants, while municipality B's employment growth has originated entirely in the chemical products industry and employment in both municipalities has grown by $5 \%$. Then our measures of

\footnotetext{
${ }^{9}$ Note that this lack of statistical significance could also emanate from strong collinearity between the regressors we use.
} 
exposure to foreign trade are not able to distinguish between the source of employment growth in each municipality, leading to imprecise coefficients.

We therefore redefine the dependent variable as follows:

$$
\Delta L_{c, t}^{2}=\frac{1}{n} \sum_{i} \frac{L_{i, c, t}-L_{i, c, t-1}}{L_{i, t-1}}
$$

Defined as such, $\Delta L_{c, t}^{2}$ reflects the overall growth contribution of each industry $i$ in municipality $c$, taking account of the size of the given municipality in the total Swiss economy and is therefore our preferred dependent variable. We display the results keeping the previous structure of specifications of the estimating equation in columns (3) and (4) of Table (6). The additional variation in $\Delta L_{c, t}^{2}$ now allows for a better identification of the various trade channels we are investigating. Relative to the results reported in columns (1) and (2), the estimated coefficients in columns (3) and (4) correspond better to our theoretical predictions and all coefficients of interest bear the expected sign and are statistically significant. For instance, a $1 \%$ appreciation of the export-weighted exchange rate in the results reported in column (3) is associated with a 3.25 percentage point decline in industry-weighted municipal employment growth, ceteris paribus and on average. This is offset by the 6.93 percentage point rise in industry-weighted municipal employment growth associated with a $1 \%$ appreciation of the imported input-weighted exchange rate. However, the overall employment effect is now negative as the coefficient of $\Delta e_{c, t}^{m c}$ is -3.76 . The combined average percentage point change in industry-weighted municpal employment growth emanating from the Franc's appreciation via the three channels is -0.075 . Thus, a $1 \%$ appreciation of the export-, intermediate-input-, and import-weighted Swiss Franc is associated with a 0.075 percentage point decline in industry-weighted municpal employment growth in the results reported in column (3), ceteris paribus and on average. ${ }^{10}$

The overall negative employment effect prevails even with the inclusion of the interaction terms in the results reported in column (4). The overall marginal effect is now calculated as the sum of $\left(\beta_{1 x}+\beta_{2 x} . x e_{c, t}\right),\left(\beta_{1 m i}+\beta_{2 m i} . m e i_{c, t}\right)$ and $\left(\beta_{1 m c}+\beta_{2 m c} . m_{e c} c t\right)$ and equals -0.12 . Thus, a $1 \%$ appreciation of the export-, intermediate-input-, and import-weighted Swiss

\footnotetext{
${ }^{10}$ Note that this is an approximation of the actual employment effect as $\Delta e_{c, t}^{x} \neq \Delta e_{c, t}^{m i} \neq \Delta e_{c, t}^{m c}$. For ease of interpretation, we prefer reporting marginal effects and assume that the three exchange rate appreciations are equal. In contrast, the actual average change in industry-weighted municpal employment growth emanating from the Franc's mean sample appreciation via the three channels, calculated using the three estimated coefficients and the mean values of the respective exchange rate changes reported in Table 4, is $\beta_{1 x} . \Delta e_{c, t}^{x}+\beta_{1 m i} . \Delta e_{c, t}^{m i}+\beta_{1 m c} . \Delta e_{c, t}^{m c}=-0.0138+0.0274-0.0151=-0.00145$.
} 
Franc is associated with a 0.12 percentage point decline in industry-weighted municpal employment growth in the results reported in column (4), ceteris paribus and on average. ${ }^{11}$ While these are average effects, the richness of our self-assembled database enables an examination of the findings across municipalities and their different sub-samples. It is also useful to examine the robustness of our results and stability of coefficients given the presence of high degrees of multicollinearity in our estimating equation. In what follows, we therefore examine the employment effects via the three channels for different sub-samples of municipalities that consider industry concentration in terms of employment, dominant language spoken, high versus low shares of cross-border commuters, and rural versus urban regions. We also compare the effects between the manufacturing and services sectors. But before that we illustrate the regional heterogeneity in the employment effects of the Franc's appreciation via the three channels on the map of Switzerland in the next sub-section.

\subsection{Regional heterogeneity in the employment effects via the three channels}

The marginal effects of the Franc's appreciation via each of the three channels are plotted on the map of Switzerland in Figure 5a; the combined employment effect of the three channels is plotted in Figure 5b. Following from the regional differences in the three exposure measures, the effects via the three channels exhibit considerable heterogeneity across municipalities. For instance, the employment effects of the Franc's appreciation via the export and imported input channels are found to be the largest in magnitude for Basel, Zürich, Bern, Geneva and St. Gallen. In contrast, the employment effect via the import competition channel is the largest in magnitude for Rüegsau, Collombey-Muraz, Cressier, Kreuzlingen and Sevelen. As mentioned above, these differences emanate from variations in the share of municipal industry employment in total industry employment and the export, imported input and import intensities of the respective industries that a particular municipality houses in each case.

Many of the municipalities exhibiting these large effects are large and very well-integrated

\footnotetext{
${ }^{11}$ Once again, this is an approximation of the actual employment effect. The actual average change in industry-weighted municpal employment growth emanating from the Franc's mean sample appreciation via the three channels is given by the sum of $\left(\beta_{1 x}+\beta_{2 x} . x e_{c, t}\right) \cdot \Delta e_{c, t}^{x} ;\left(\beta_{1 m i}+\beta_{2 m i} . m e i_{c, t}\right) \cdot \Delta e_{c, t}^{m i}$; and $\left(\beta_{1 m c}+\beta_{2 m c} . m e c_{c, t}\right) . \Delta e_{c, t}^{m c}$. This is calculated using the six estimated coefficients and the mean values of the respective exchange rate changes and municipality-level exposure variables reported in Table 4, which equals $-0.0117+0.0214-0.0111=-0.00136$.
} 
with foreign markets (in terms of export and import intensities). These cities host multinational firms and are major entry and exit points through their location vis-a-vis the Swiss transport network (airports, railways, highways) for products to and from Switzerland. For instance, the wholesale and machinery and equipment sectors are important drivers behind the large effects observed for both Zürich and Basle. For Zürich, the financial sector, and for Basle, the chemicals and transport and storage sectors are other important determinants of the observed large effects. In the case of Bern, the large effects emanate from the city's importance in R\&D and other business activities.

In some instances, the estimated effects at the regional level do not directly correspond to the exposure measures because the concerned municipalities may be employing fewer people in sectors that are otherwise outwardly-oriented. For instance, the export exposure measures for the canton of Geneva are the largest for the basic metals, motor vehicles and chemicals sectors, but the average share of total employment in these sectors for our sample period is only $2.3 \%$. Similarly, the city of Basel shows the largest employment effects (in magnitude) via the first two channels but not via the third channel, which can be explained by the dominance of its industrial structure in the chemicals sector, which faces little import competition.

Finally, note that despite the regional heterogeneity evident in Figures 5a and 5b, the following generalizations seem to hold: (a) regions that are more strongly exposed to export competition, also profit more strongly from the positive effects of the imported input channel; (b) the negative effects of stronger export and import competition tend to be more regionally concentrated, while the positive effects of the imported input channel are more widespread across municipalities; and (c) there is more dispersion in the values of the employment effects via the export and imported input channels around the respective means relative to the values of the employment effect via the import competition channel.

\section{$<$ Insert Figures 5a and 5b here $>$}

\subsection{Results for various sub-samples of municipalities}

In this sub-section, we examine the sensitivity of our baseline results to different subsamples of municipalities that consider varying levels of industry concentration in terms of employment (defined as industry employment shares in total municipal employment exceeding 1\%, 5\% and 10\%, respectively), dominant language spoken (German, French or 
Italian), high versus low shares of cross-border commuters in total municipal employment (with the threshold defined at the 10\% level), and for rural versus urban regions of Switzerland (a municipality is regarded as urban if it's population exceeds 20000 or population density exceeds 500).

We also consider sub-samples of industry concentration in terms of employment in specific industries - agriculture, forestry, fishing (AFF); computer, electronic and optical equipment $(\mathrm{CEOE})$; and hotels and restaurant $(\mathrm{H} \& \mathrm{R})$ - to examine the employment effects of the Franc's appreciation via the three channels for municipalities concentrated in Switzerland's niche sectors like agri-products, watches and tourism.

The results from all these regressions are reported in Table 7. In each case, for the ease of interpretation, we again report the marginal effects and assume that the exchange rate appreciations via the three channels are equal in magnitude.

\section{$<$ Insert Table 7 here $>$}

In a departure from the findings for the full sample, Table 7 reveals positive employment effects of the Franc's appreciation in the AFF and CEOE sectors (alluding to the inelastic demand for Swiss products in these sectors resulting in the opposite signs of the coefficients of the imported input and import competition channels); in the tourism sector (emanating from the dominance of the imported input channel); in the sub-sample of municipalities with the share of cross-border commuters exceeding 10\% (possibly emanating from the ability to hire more cross-border communters); and in municipalities where the share of industry employment in total employment was above $10 \%$ (likely a threshold effect as the positive impact is reversed when the employment share is reduced to $5 \%$ and $1 \%$ ). In all the remaining sub-samples, the overall employment effect of the Franc's appreciation is found to be negative; for rural municipalities, the combined effect is marginally positive.

\subsection{Results for manufacturing vs services}

In this sub-section, we present the results from estimating the baseline equation (8) for industry-weighted manufacturing and services employment growth separately to examine the robustness of the overall findings to the inclusion of the servcies sector in the sample. These estimations employ year and municipality fixed effects and standards errors are clustered at the municipal level. All regressors are now constructed specific to the manufacturing and services sectors in the respective estimations. 
These results are reported in Table 8. Again, we report the marginal percentage point change in services and manufacturing employment growth emanating from a $1 \%$ appreciation of the export-, imported-input- and import-weighted Swiss Franc but only specific to the services and manufacturing sectors, respectively. The own effect of services-sector specific regressors on industry-weighted services employment growth is found to be negative on the whole in these results with the effects of the three channels as hypothesized. In contrast, the own effect of manufacturing-sector specific regressors on industry-weighted manufacturing employment growth is found to be slightly positive on the whole, with the effect of the import channel being statistically indifferent from zero.

\section{$<$ Insert Table 8 here $>$}

The results in this sub-section suggest that the overall findings may be influenced by the inclusion of the services sector in the study's sample.

\section{Conclusion}

In this paper, we have exploited exogenous exchange rate movements to identify tradeinduced shocks across all sectors of the Swiss economy and transposed industry-level exposures to the municipal level, using detailed employment data on the entirety of Swiss firms. In line with theoretical predictions, we find strong evidence for three channels of employment effects of currency appreciation in the short- to medium-term: negative employment growth induced by increasing export uncompetitiveness and higher import competition, and positive employment growth induced by cheaper availability of foreign inputs. The combined average effect of the three channels on employment growth is negative in our preferred results, with significant heterogeneity across municipalities and for sub-samples that that consider industry concentration in terms of employment, dominant language spoken, high versus low shares of cross-border commuters, and rural versus urban regions. Consistent with the predominant role played by the services sector in Swiss employment and trade, we find the overall findings being driven by the inclusion of the services sector in the study's sample. Further research may investigate the qualitative dimension of labor market adjustments more closely. Moreover to the extent that data availability makes this possible, an extension towards wages and part-time work may build upon the methodology developed in this paper and provide evidence beyond adjustment in total hours worked. 


\section{References}

Auer R. and P. Sauré (2012). CHF strength and Swiss export performance? Evidence and outlook from a disaggregate analysis. Applied Economics Letters 19(6): 521-531.

Auer, R., P. Sauré, et al.(2011). Export basket and the effects of exchange rates on exports? Why Switzerland is special. Globalization and Monetary Policy Institute Working Paper, 77.

Autor, D. H., D. Dorn and G. H. Hanson (2013). 'The China Syndrome: Local Labor Market Effects of Import Competition in the United States', American Economic Review 103(6): 2121-68.

Autor, D. H., D. Dorn and G. H. Hanson (2016). 'The China Shock: Learning from Labor Market Adjustment to Large Changes in Trade', Annual Review of Economics 8(1): 205-240.

Baltensperger, E., and P. Kugler (2016). The historical origins of the safe haven status of the Swiss Franc. Aussenwirtschaft 67.2: 1-27.

Bernard, A. B., Jensen, J. B., Redding, S. J., and Schott, P. K. (2011). The empirics of firm heterogeneity and international trade (No. w17627). National Bureau of Economic Research.

Black, A. J., and McMillan, D. G. (2004). Long run trends and volatility spillovers in daily exchange rates. Applied Financial Economics, 14(12), 895-907.

Campa, J. M. and L. S. Goldberg (2001). Employment versus wage adjustment and the US dollar. Review of Economics and Statistics 83(3): 477-489.

Egger, H., P. Egger and U. Kreickemeier (2013). Trade, wages, and profits. European Economic Review 64(11): 332-350.

Egger, P. and S. Nigai (2015). Structural gravity with dummies only: Constrained ANOVAtype estimation of gravity models. Journal of International Economics 97(1): 86-99.

Fauceglia, D., A. Shingal, and M. Wermelinger (2014). 'Natural hedging' of exchange rate risk: The role of imported input prices. Swiss Journal of Economics and Statistics 150(4): 261-296.

Fauceglia, D., A. Lassmann, A. Shingal, and M. Wermelinger (2015). Backward participation in global value chains and exchange rate driven adjustments of Swiss exports. Study on behalf of the State Secretariat for Economic Affairs (SECO), Strukturberichterstattung Nr. $53 / 2$. 
Goldberg, L. S. (2004). Industry-specific exchange rates for the United States. Federal Reserve Bank of New York Economic Policy Review 10(1).

Huang, H. and Y. Tang (2015). How did exchange rates affect employment in US cities? Contemporary Economic Policy.

Kaiser, B. and M. Siegenthaler (2016). The skill-biased effects of exchange rate fluctuations. The Economic Journal 126(592): 756-780.

Klein, M. W., Schuh, S., and Triest, R. K. (2003). Job creation, job destruction, and the real exchange rate. Journal of International Economics 59(2), 239-265.

Lassmann, A.(2013). Exchange rate transmission and export activity at the firm level.

Mian, A. R. and A. Sufi (2012). What explains high unemployment? The aggregate demand channel. Technical report, National Bureau of Economic Research.

Nucci, F. and A. F. Pozzolo (2010). The exchange rate, employment and hours: What firm-level data say. Journal of International Economics 82(2): 112-123.

OECD (2015): Inter-Country Input-Output database: https://www.oecd.org/sti/ind/input-outputtablesedi downloaded on 19.11.2016

Schwarzer, J.(2016). Trade and employment. Deutsche Gesellschaft fuer internationale Zusammenarbeit (GIZ).

Timmer, M. P., Dietzenbacher, E., Los, B., Stehrer, R. and de Vries, G. J. (2015). 'An Illustrated User Guide to the World Input-Output Database: the Case of Global Automotive Production'. Review of International Economics 23: 575-605 
Peter H. Egger, Johannes Schwarzer and Anirudh Shingal

Figure 1: Bilateral nominal exchange rates, 1999=100



Source: UNCTAD Stat

Figure 2: Share of FTE and total FTE when FTE $>=0.5$

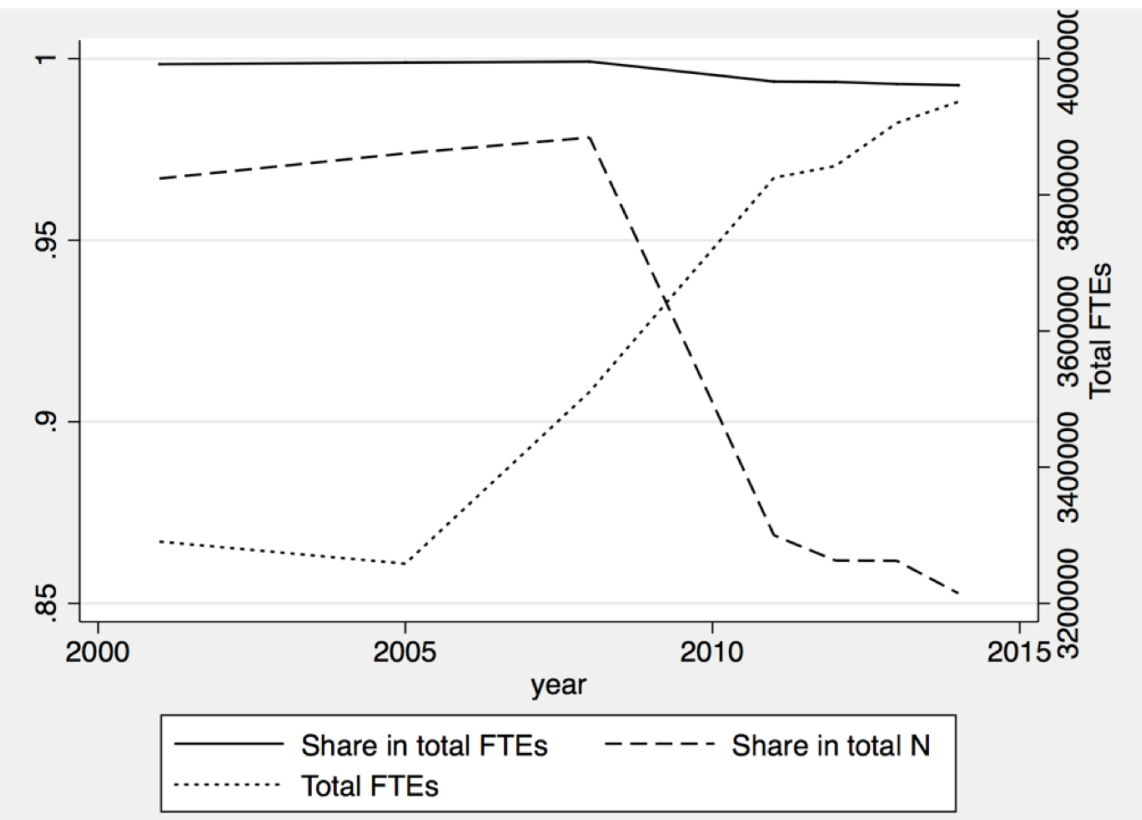

Source: BFS STATENT

Note: The dotted line is measured on the right vertical axis. 


\section{Figure 3: Average industry-specific exchange rate change}

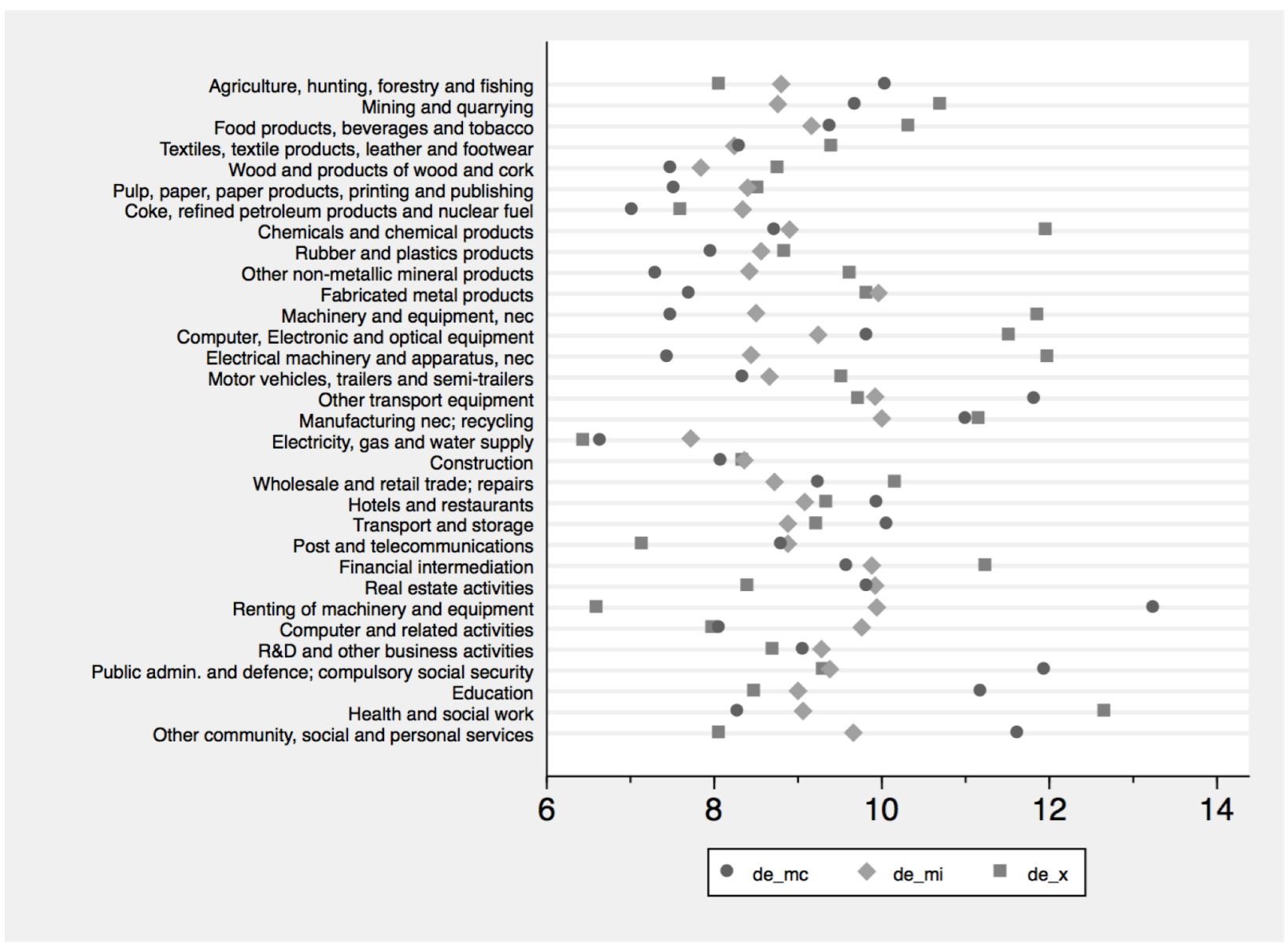

Source: Authors' calculations

Note: The figure displays the values of the industry-specific, trade-weighted exchange rate changes facing consumption imports (de_mc shown as dots), intermediate imports (de_mi shown as diamonds) and exports (de_x shown as squares). For instance, exports of electricity, gas and water supply face a lower appreciation value than exports of chemicals and chemical products. This is because the former is entirely exported into the Euro area, whereas chemical products are also exported substantially into e.g. the US; and the CHF has appreciated more against the USD than against the EUR, which explains the higher value of de_x for chemical products compared to the utilities sector. 
Peter H. Egger, Johannes Schwarzer and Anirudh Shingal

Figure 4: Municipal employment growth



Note: Figure pertains to the median Swiss municipality. 
Figure 5a: Regional heterogeneity in employment effects emanating from the Swiss Franc's appreciation via the three channels
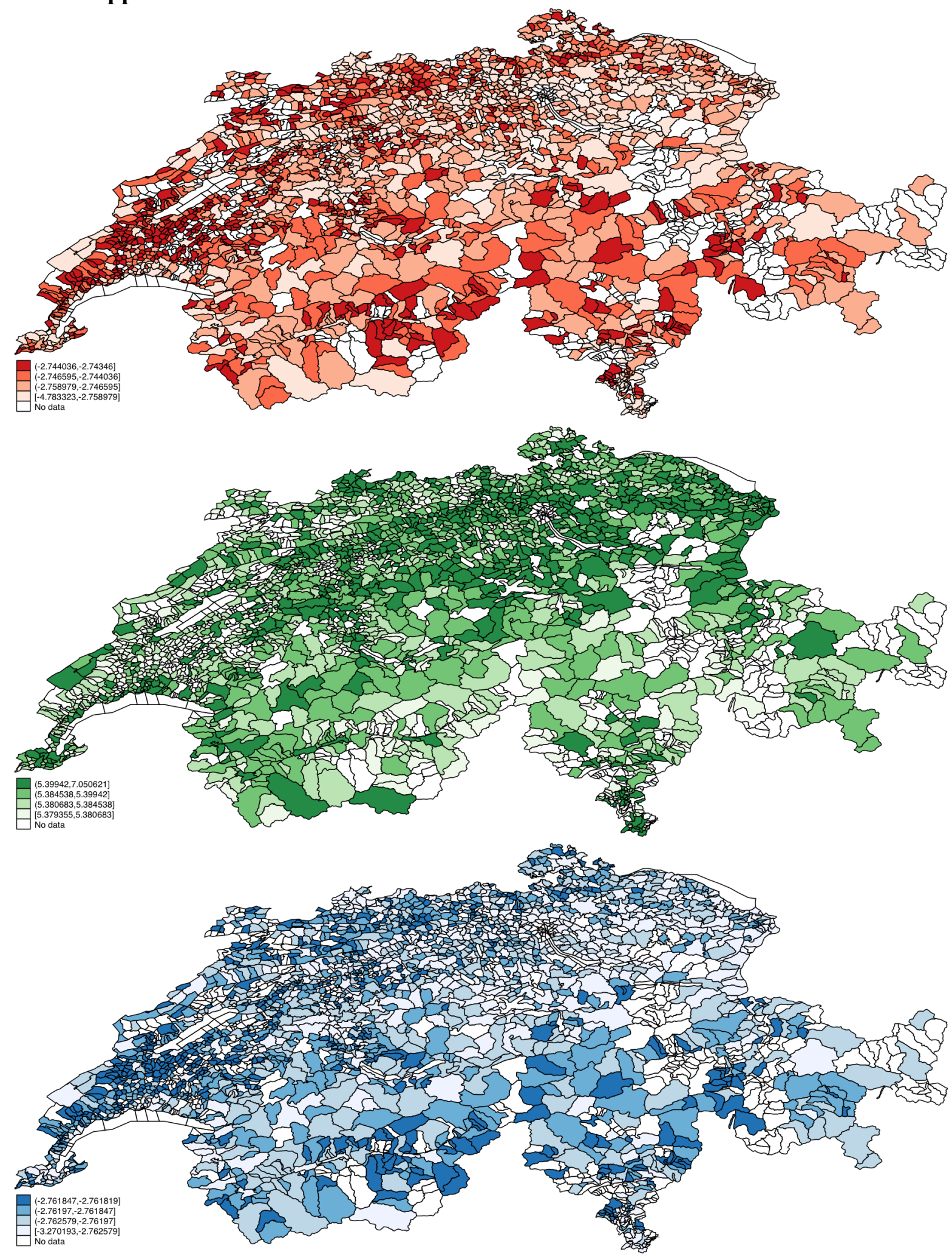

Note: The red map plots percentage point changes in employment growth emanating from a $1 \%$ appreciation of the export-weighted exchange rate across municipalities; the green map plots these changes relative to the intermediate input-weighted exchange rate; and the blue map plots these changes relative to the import competition-weighted exchange rate. 
Figure 5b: Regional heterogeneity in employment effects emanating from the Swiss Franc's appreciation: combined effect of the three channels

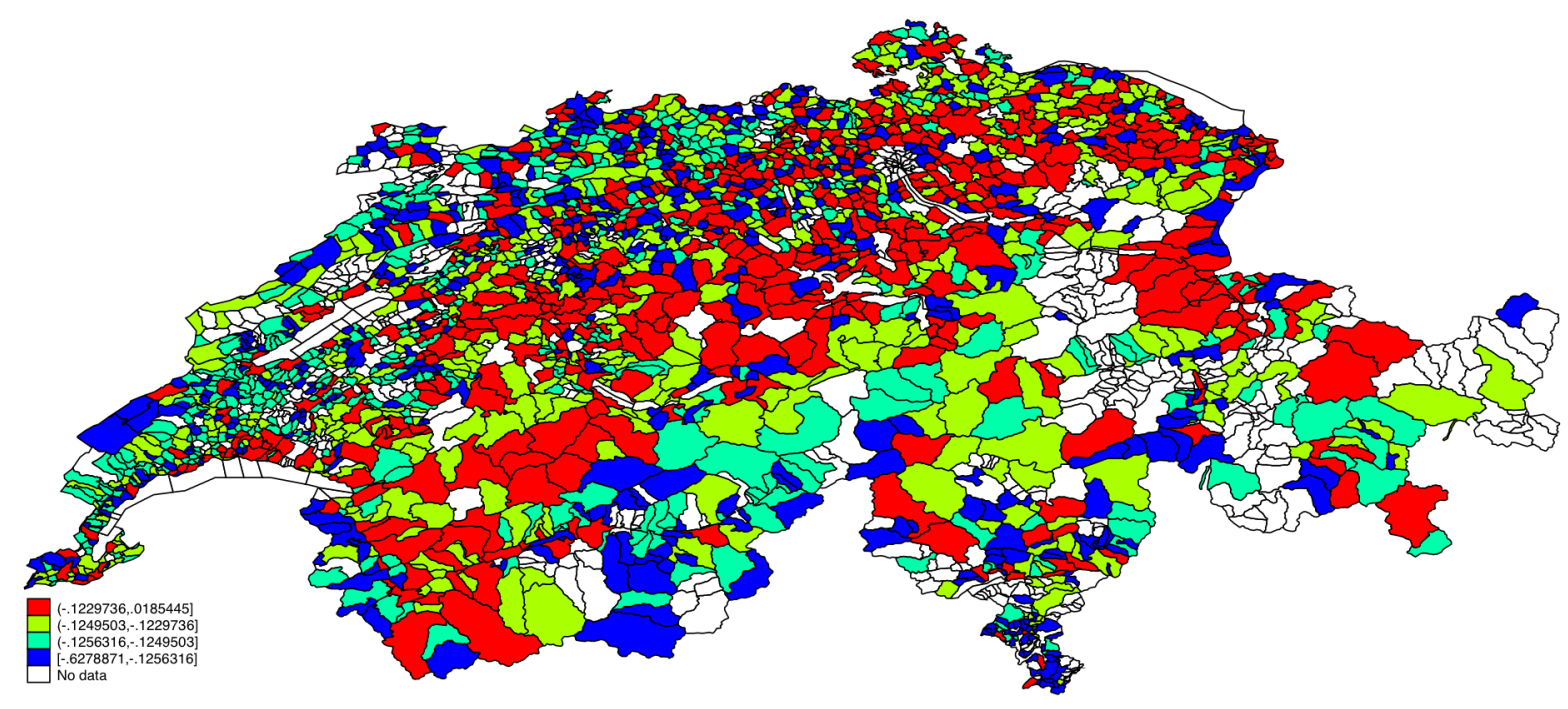


Table 1: Employment summary statistics

\begin{tabular}{|c|c|c|c|c|c|}
\hline $\begin{array}{l}\text { NOGA } 2002 \\
\text { codes }\end{array}$ & Industry description & $\begin{array}{c}\text { FTE share } \\
2001\end{array}$ & $\begin{array}{c}\text { FTE share } \\
2014\end{array}$ & $\begin{array}{l}\text { Industry } \\
\text { growth }\end{array}$ & $\begin{array}{c}\text { Contribution to } \\
\text { growth }\end{array}$ \\
\hline $1,2,5$ & Agriculture, hunting, forestry and fishing & 4.15 & 3.00 & -12.87 & -0.53 \\
\hline $10,11,12,13,14$ & Mining and quarrying & 0.13 & 0.12 & 9.32 & 0.01 \\
\hline 15,16 & Food products, beverages and tobacco & 1.72 & 1.88 & 31.36 & 0.54 \\
\hline $17,18,19$ & Textiles, textile products, leather and footwear & 0.61 & 0.32 & -35.76 & -0.22 \\
\hline 20 & Wood and products of wood and cork & 1.06 & 0.90 & 2.39 & 0.03 \\
\hline 21,22 & Pulp, paper, paper products, printing and publishing & 1.90 & 1.06 & -32.71 & -0.62 \\
\hline 23 & Coke, refined petroleum products and nuclear fuel & 0.02 & 0.02 & 25.03 & 0.01 \\
\hline 24 & Chemicals and chemical products & 1.88 & 1.78 & 14.29 & 0.27 \\
\hline 25 & Rubber and plastics products & 0.72 & 0.56 & -5.73 & -0.04 \\
\hline 26 & Other non-metallic mineral products & 0.56 & 0.42 & -9.23 & -0.05 \\
\hline 27 & Basic metals & 0.49 & 0.31 & -23.27 & -0.11 \\
\hline 28 & Fabricated metal products & 2.50 & 2.00 & -3.29 & -0.08 \\
\hline 29 & Machinery and equipment, nec & 3.11 & 2.18 & -15.49 & -0.48 \\
\hline $30,32,33$ & Computer, Electronic and optical equipment & 2.92 & 2.95 & 21.80 & 0.64 \\
\hline 31 & Electrical machinery and apparatus, nec & 1.06 & 0.89 & 1.44 & 0.02 \\
\hline 34 & Motor vehicles, trailers and semi-trailers & 0.14 & 0.11 & -3.54 & -0.01 \\
\hline 35 & Other transport equipment & 0.39 & 0.40 & 21.62 & 0.08 \\
\hline 36,37 & Manufacturing nec; recycling & 0.85 & 0.66 & -6.00 & -0.05 \\
\hline 40,41 & Electricity, gas and water supply & 0.69 & 0.70 & 20.70 & 0.14 \\
\hline 45 & Construction & 8.39 & 8.11 & 16.36 & 1.37 \\
\hline $50,51,52$ & Wholesale and retail trade; repairs & 15.64 & 13.08 & 0.69 & 0.11 \\
\hline 55 & Hotels and restaurants & 5.85 & 4.78 & -1.47 & -0.09 \\
\hline $60,61,62,63$ & Transport and storage & 4.66 & 4.58 & 18.26 & 0.85 \\
\hline
\end{tabular}




\begin{tabular}{|c|c|c|c|c|c|}
\hline \multicolumn{6}{|c|}{ Peter H. Egger, Johannes Schwarzer and Anirudh Shingal } \\
\hline 64 & Post and telecommunications & 2.29 & 1.51 & -20.67 & -0.47 \\
\hline $65,66,67$ & Financial intermediation & 5.97 & 5.38 & 8.59 & 0.51 \\
\hline 70 & Real estate activities & 0.59 & 1.18 & 140.96 & 0.83 \\
\hline 71 & Renting of machinery and equipment & 0.12 & 0.17 & 70.44 & 0.09 \\
\hline 72 & Computer and related activities & 1.82 & 2.14 & 41.54 & 0.76 \\
\hline 73,74 & $\mathrm{R} \& \mathrm{D}$ and other business activities & 8.28 & 12.51 & 82.09 & 6.80 \\
\hline 75 & Public admin. and defence; compulsory social security & 4.03 & 4.29 & 28.09 & 1.13 \\
\hline 80 & Education & 4.90 & 5.27 & 29.60 & 1.45 \\
\hline 85 & Health and social work & 9.14 & 11.84 & 56.01 & 5.12 \\
\hline $90,91,92,93$ & Other community, social and personal services & 3.43 & 4.89 & 71.66 & 2.46 \\
\hline
\end{tabular}


Table 2: Trade intensities of ICIO industries

\begin{tabular}{llccc}
\hline NOGA 2002 codes & Industry description & Exports & Imports & Inputs \\
\hline $1,2,5$ & Agriculture, hunting, forestry and fishing & 0.01 & 0.05 & 0.13 \\
$10,11,12,13,14$ & Mining and quarrying & 0.12 & 0.13 & 0.11 \\
15,16 & Food products, beverages and tobacco & 0.14 & 0.12 & 0.13 \\
$17,18,19$ & Textiles, textile products, leather and footwear & 0.64 & 1.34 & 0.34 \\
20 & Wood and products of wood and cork & 0.08 & 0.01 & 0.14 \\
21,22 & Pulp, paper, paper products, printing and publishing & 0.20 & 0.07 & 0.17 \\
23 & Coke, refined petroleum products and nuclear fuel & 0.30 & 4.53 & 0.17 \\
24 & Chemicals and chemical products & 0.73 & 0.16 & 0.17 \\
25 & Rubber and plastics products & 0.47 & 0.08 & 0.32 \\
26 & Other non-metallic mineral products & 0.16 & 0.04 & 0.18 \\
27 & Basic metals & 0.76 & 0.04 & 0.32 \\
28 & Fabricated metal products & 0.23 & 0.03 & 0.22 \\
29 & Machinery and equipment, nec & 0.60 & 0.26 & 0.21 \\
$30,32,33$ & Computer, Electronic and optical equipment & 0.53 & 0.18 & 0.20 \\
31 & Electrical machinery and apparatus, nec & 0.38 & 0.13 & 0.28 \\
34 & Motor vehicles, trailers and semi-trailers & 0.77 & 4.76 & 0.39 \\
35 & Other transport equipment & 0.39 & 0.57 & 0.25 \\
36,37 & Manufacturing nec; recycling & 0.68 & 0.51 & 0.27 \\
40,41 & Electricity, gas and water supply & 0.15 & 0.02 & 0.08 \\
45 & Construction & 0.00 & 0.02 & 0.14 \\
$50,51,52$ & Wholesale and retail trade; repairs & 0.25 & 0.11 & 0.08 \\
55 & Hotels and restaurants & 0.21 & 0.15 & 0.08 \\
$60,61,62,63$ & Transport and storage & 0.28 & 0.20 & 0.11 \\
64 & Post and telecommunications & 0.08 & 0.03 & 0.08 \\
$65,66,67$ & Financial intermediation & 0.32 & 0.01 & 0.02
\end{tabular}


Peter H. Egger, Johannes Schwarzer and Anirudh Shingal

Renting of machinery and equipment

0.15

0.02

0.11

Computer and related activities

0.00

0.01

0.04

\section{R\&D and other business activities}

0.03

0.00

0.05

Public admin. and defence; compulsory social security

0.03

$0.00 \quad 0.03$

Education

0.01

$0.00 \quad 0.05$

85

Health and social work

$0.03 \quad 0.00$

0.08

Other community, social and personal services

0.12

0.11

0.09 
Labour market effects of currency appreciation: The case of Switzerland

Table 3: Average exchange rate change by sector

\begin{tabular}{lccc}
\hline Sector & $\Delta \mathbf{e}^{\mathbf{x}}$ & $\Delta \mathbf{e}^{\mathbf{m c}}$ & $\Delta \mathbf{e}^{\mathbf{m i}}$ \\
\hline & & & \\
Manufacturing & $10.55 \%$ & $8.52 \%$ & $8.93 \%$ \\
Services & $8.81 \%$ & $9.71 \%$ & $9.18 \%$ \\
\hline
\end{tabular}

Note: Manufacturing comprises NOGA codes 15-37 and services

comprises NOGA codes 50-52, 55, 60-67, 70-75, 80, 85, 90-93.

Table 4: Descriptive statistics

\begin{tabular}{lccccc}
\hline Variable & Obs & Mean & Std. Dev. & Min & Max \\
\hline$\Delta \mathrm{L}_{\mathrm{c}, \mathrm{t}}^{1}$ & 9136 & 3.757571 & 20.93911 & -83.0442 & 449.7979 \\
$\Delta \mathrm{L}_{\mathrm{c}, \mathrm{t}}$ & 9136 & 0.0014746 & 0.0200647 & -0.4148575 & 0.947761 \\
$\Delta \mathrm{GDP}_{\mathrm{c}, \mathrm{t}}$ & 9136 & 0.0102382 & 0.0637368 & -0.0020827 & 3.510124 \\
$\Delta \mathrm{e}_{\mathrm{c}, \mathrm{t}}^{\mathrm{r}}$ & 9136 & 0.0042421 & 0.0274679 & -0.0133255 & 1.679724 \\
$\Delta \mathrm{e}^{\mathrm{mc}}{ }_{\mathrm{c}, \mathrm{t}}$ & 9136 & 0.0040031 & 0.0283389 & -0.0222461 & 1.738849 \\
$\Delta \mathrm{e}^{\mathrm{mi}}{ }_{\mathrm{c}, \mathrm{t}}$ & 9136 & 0.0039543 & 0.0283452 & -0.0042345 & 1.754438 \\
$\mathrm{xe}_{\mathrm{c}, \mathrm{t}}$ & 9136 & 0.0117614 & 0.0445519 & $9.83 \mathrm{E}-08$ & 1.157416 \\
$\mathrm{mec}_{\mathrm{c}, \mathrm{t}}$ & 9136 & 0.0181875 & 0.2038247 & $6.63 \mathrm{E}-07$ & 10.34096 \\
$\mathrm{mei}_{\mathrm{c}, \mathrm{t}}$ & 9136 & 0.0067475 & 0.0227712 & $1.40 \mathrm{E}-06$ & 0.5788761 \\
\hline
\end{tabular}

Table 5: Top ten municipality export exposure ranking

\begin{tabular}{lcccc}
\hline Municipality & $\mathbf{2 0 0 5}$ & $\mathbf{2 0 0 8}$ & $\mathbf{2 0 1 1}$ & $\mathbf{2 0 1 4}$ \\
\hline Zürich & 2 & 2 & 2 & 1 \\
Basel & 1 & 1 & 1 & 2 \\
Genève & 7 & 4 & 4 & 3 \\
Kreuzlingen & 10 & 6 & 6 & 4 \\
Mendrisio & 32 & 20 & 9 & 5 \\
Bern & 6 & 3 & 3 & 6 \\
St. Gallen & 9 & 5 & 5 & 7 \\
Sevelen & 21 & 7 & 7 & 8 \\
Biel/Bienne & 14 & 14 & 11 & 9 \\
Baden & 17 & 15 & 24 & 10 \\
\hline
\end{tabular}


Peter H. Egger, Johannes Schwarzer and Anirudh Shingal

Table 6: Baseline estimates: municipal employment growth and industryweighted employment growth

\begin{tabular}{|c|c|c|c|c|}
\hline & \multicolumn{2}{|c|}{ Employment growth } & \multicolumn{2}{|c|}{$\begin{array}{c}\text { Industry-weighted emp } \\
\text { grth }\end{array}$} \\
\hline & (1) & (2) & (3) & (4) \\
\hline & $\Delta \mathbf{L}_{\mathrm{c}, \mathrm{t}}^{1}$ & $\Delta \mathbf{L}_{\mathrm{c}, \mathrm{t}}^{1}$ & $\Delta \mathbf{L}_{\mathrm{c}, \mathrm{t}}^{2}$ & $\Delta \mathbf{L}_{\mathrm{c}, \mathrm{t}}^{2}$ \\
\hline$\Delta \mathrm{e}_{\mathrm{c}, \mathrm{t}}^{\mathrm{x}}$ & $\begin{array}{l}-55.19 \\
(59.17)\end{array}$ & $\begin{array}{l}-85.20 \\
(109.3)\end{array}$ & $\begin{array}{c}-3.246^{* * *} \\
(0.821)\end{array}$ & $\begin{array}{c}-2.743 * * * \\
(0.568)\end{array}$ \\
\hline$\Delta \mathrm{e}_{\mathrm{c}, \mathrm{t}}^{\mathrm{x}} * \mathrm{xe}_{\mathrm{c}, \mathrm{t}}$ & & $\begin{array}{l}-74.93 * \\
(43.91)\end{array}$ & & $\begin{array}{c}-1.876^{* * *} \\
(0.32)\end{array}$ \\
\hline$\Delta \mathrm{e}_{\mathrm{c}, \mathrm{t}}^{\mathrm{mi}}$ & $\begin{array}{c}379.1 * * * \\
(103.1)\end{array}$ & $\begin{array}{c}176.0 \\
(198.0)\end{array}$ & $\begin{array}{c}6.930 * * * \\
(1.496)\end{array}$ & $\begin{array}{l}5.379 * * * \\
(1.546)\end{array}$ \\
\hline$\Delta \mathrm{e}_{\mathrm{c}, \mathrm{t}}^{\mathrm{mi}} * \mathrm{mei}_{\mathrm{c}, \mathrm{t}}$ & & $\begin{array}{l}161.16^{*} \\
(87.49)\end{array}$ & & $\begin{array}{c}3.788 * * * \\
(0.526)\end{array}$ \\
\hline$\Delta \mathrm{e}_{\mathrm{c}, \mathrm{t}}^{\mathrm{mc}}$ & $\begin{array}{c}-330.1 * * * \\
(85.62)\end{array}$ & $\begin{array}{l}-111.6 \\
(122.5)\end{array}$ & $\begin{array}{c}-3.759 * * * \\
(1.263)\end{array}$ & $\begin{array}{l}-2.762 * \\
(1.626)\end{array}$ \\
\hline$\Delta \mathrm{e}_{\mathrm{c}, \mathrm{t}}^{\mathrm{mc}} * \mathrm{mec}_{\mathrm{c}, \mathrm{t}}$ & & $\begin{array}{c}10.94 \\
(16.59)\end{array}$ & & $\begin{array}{l}-0.137 \\
(0.114)\end{array}$ \\
\hline$\Delta \mathrm{GDP}_{\mathrm{c}, \mathrm{t}}^{*}$ & $\begin{array}{l}7.344 * * \\
(3.173)\end{array}$ & $\begin{array}{l}-0.778 \\
(4.830)\end{array}$ & $\begin{array}{l}-0.0629 \\
(0.0633)\end{array}$ & $\begin{array}{l}-0.0957 \\
(0.105)\end{array}$ \\
\hline $\mathrm{xe}_{\mathrm{c}, \mathrm{t}}$ & & $\begin{array}{c}33.47 \\
(45.04)\end{array}$ & & $\begin{array}{c}0.368 \\
(0.410)\end{array}$ \\
\hline $\operatorname{mec}_{\mathrm{c}, \mathrm{t}}$ & & $\begin{array}{l}-4.776 \\
(3.371)\end{array}$ & & $\begin{array}{l}-0.0311 \\
(0.026)\end{array}$ \\
\hline $\mathrm{mei}_{\mathrm{c}, \mathrm{t}}$ & & $\begin{array}{c}-389.0 * * * \\
(135.4)\end{array}$ & & $\begin{array}{l}-1.793 * \\
(0.954)\end{array}$ \\
\hline Constant & $\begin{array}{c}-1.588 * * * \\
(0.489)\end{array}$ & $\begin{array}{c}0.824 \\
(0.736)\end{array}$ & $\begin{array}{c}0.0045^{* *} \\
(0.002)\end{array}$ & $\begin{array}{c}0.0127 * * * \\
(0.004)\end{array}$ \\
\hline Observations & 9,136 & 9,136 & 9,136 & 9,136 \\
\hline R-squared & 0.238 & 0.241 & 0.582 & 0.668 \\
\hline
\end{tabular}

Note: Standard errors, clustered at the municipal level, in parentheses. All estimations include municipality and year fixed effects. Levels of significance: *** $(1 \%), * *(5 \%), *(10 \%)$. 


\begin{tabular}{|c|c|c|c|c|}
\hline \% point change in e & ent growth ema & lating from a 1 & o appreciation & the Swiss \\
\hline & Channel 1 & Channel 2 & Channel 3 & Overall \\
\hline Sub-sample of: & & & & \\
\hline Labour share $>0.01$ & $-2.87124 * * *$ & $6.235126^{* * *}$ & $-3.471268 * * *$ & $-0.107382 * * *$ \\
\hline Labour share $>0.05$ & $-2.227193^{*}$ & $0.127515^{* * *}$ & $0.0796905 * * *$ & $-2.019987^{*}$ \\
\hline Labour share $>0.1$ & $-4.098277 * *$ & $11.10071 * *$ & $.2392165^{* *}$ & $7.241645^{* *}$ \\
\hline Urban & $-3.167939 * * *$ & $6.149557 * * *$ & $-3.119101 *$ & $-0.137483 * * *$ \\
\hline Rural & $-0.055461 * * *$ & $0.1116501 * * *$ & $-0.020314 * * *$ & $0.0358752 * * *$ \\
\hline $\mathrm{AFF}$ & $-9.741298 * * *$ & $-4.845284 * * *$ & $15.36244 * *$ & $0.775859 * *$ \\
\hline CEOE & $-.3558164 * * *$ & $-1.226095^{* * *}$ & $2.333714 * * *$ & $0.7518035 * * *$ \\
\hline Hotels \& restaurants & $-24.907 * * *$ & $60.52 * * *$ & $-35.174 * * *$ & $0.438364 * * *$ \\
\hline Commuters & $-2.919618 * * *$ & $4.797433 * * *$ & -1.998735 & $1.877815^{* * *}$ \\
\hline Non-commuters & $-2.356242 * * *$ & $4.768217 * * *$ & $-2.46623 * * *$ & $-0.054255^{* * *}$ \\
\hline German & $-2.635181 * * *$ & $6.504459 * * *$ & $-4.127429 * * *$ & $-0.258151 * * *$ \\
\hline French & $-2.988796^{* * *}$ & $0.0742365 * * *$ & $-0.0102619 * *$ & $-2.924821 * * *$ \\
\hline Italian & $-2.327501^{* *}$ & $0.2102448 * *$ & $-0.0676156^{* *}$ & $-2.184871 * *$ \\
\hline
\end{tabular}

Note: Table reports percentage point change in industry-weighted employment growth emanating from a $1 \%$ appreciation of the CHF via exports (1), intermediate inputs (2) and import (3) channels as well as the sum of these effects. All estimations include municipality and year fixed effects, with the standard errors clustered by municipality. $\mathrm{AFF}=$ Agriculture, forestry, fishing $; \mathrm{CEOE}=$ Computer, electronic \& optical equipment. Levels of significance: $* * *$ $(1 \%), * *(5 \%), *(10 \%)$. Statistically insignificant effects are not considered while calculating the individual and overall effects. 
Table 8: Results for services versus manufacturing

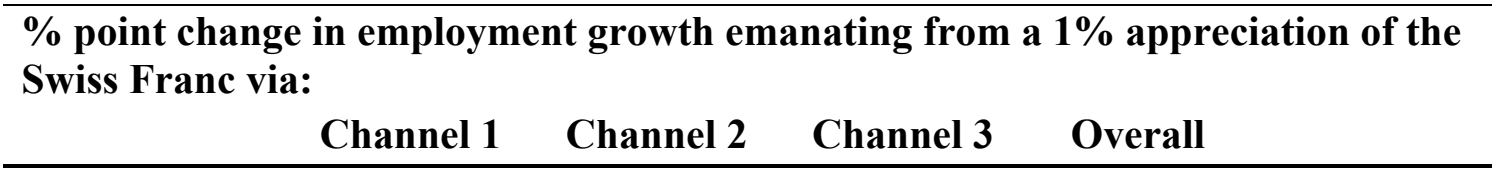

\section{in SERVICES}

\section{Sub-sample \\ of:}

Services $\quad-10.147 * * * \quad 7.424457 * * * 160.016 * * * 2.7396 * * *$

in MANUFACTURING

Manufacturing $\quad-2.19852^{* *} \quad 2.469616^{*} \quad-0.7459354 \quad 0.2710955^{*}$

Note: Table reports percentage point change in industry-weighted employment growth emanating from a $1 \%$ appreciation of the CHF via exports (1), intermediate inputs (2) and import (3) channels as well as the sum of these effects. All estimations include municipality and year fixed effects, with the standard errors clustered by municipality. Levels of significance: $* * *(1 \%), * *(5 \%), *(10 \%)$. Statistically insignificant effects are not considered while calculating the individual and overall effects. Manufacturing comprises NOGA codes 15-37 and services comprises NOGA codes 50-52, 55, 60-67, 70-75, 80, 85, 90-93. 


\section{Author contacts:}

\section{Peter H. Egger}

ETH Zurich, Department of Management, Technology, and Economics

Leonhardstr. 21

8092 Zurich

Switzerland

E-mail: egger@kof.ethz.ch

\section{Johannes Schwarzer}

Council on Economic Policies

Zurich

Email: js@cepweb.org

\section{Anirudh Shingal (corresponding author)}

Robert Schuman Centre for Advanced Studies, European University Institute Villa Schifanoia, Via Boccaccio 121

I-50133 Florence

Email: anirudh.shingal@eui.eu; 